\title{
Necrotic cutaneous vasculitic skin lesions: a case of atypical Henoch-Schönlein purpura in a child with heterozygosity for factor $\mathrm{V}$ Leiden
}

\author{
Sacha Dhanjal, ${ }_{1}{ }^{*}$ Anja Saso, ${ }^{1}$ Despina Eleftheriou, ${ }^{2}$ Sue Laurent ${ }^{1}$
}

${ }^{1}$ Paediatrics, Barnet General Hospital, Royal Free London NHS Foundation Trust, London, UK

${ }^{2}$ Paediatric and Adolescent Rheumatology, Great Ormond Street Hospital for Children NHS Trust, London, UK

\section{Correspondence to}

Dr Sacha Dhanjal,

s.dhanjal@nhs.net

Accepted 26 February 2017

\section{DESCRIPTION}

A Caucasian boy aged 5 years presented with acute onset of a non-tender, palpable purpuric rash to his lower limbs, preceded by a mild upper respiratory tract infection. Clinical findings were consistent with Henoch-Schönlein purpura (HSP) and he was discharged with community follow-up to monitor his lesions, blood pressure and urinalysis.

However, he clinically deteriorated over the following week with two further admissions due to evolving purpuric skin lesions (figure 1) and development of severe joint pain requiring opioid analgesia. There was no clinical evidence of renal or intestinal involvement.

Over a subsequent 6-week period, his purpuric lesions progressed to full thickness skin necrosis (figure 2). This was confirmed by a plastic surgery assessment and he was referred for a tertiary rheumatology review. He underwent a series of investigations which showed negative antinuclear and antineutrophil cytoplasmic antibodies, absence of an acute phase response and normal visceral angiography. He had a transient low protein $S$ level (which normalised subsequently) and low activated Protein C resistance. Genetic testing showed heterozygosity for factor V Leiden mutation. A skin biopsy revealed mild ongoing perivascular inflammation.

Given the extent of cutaneous involvement and persistence of active inflammation in the skin biopsy, he was started on azathioprine $(2 \mathrm{mg} / \mathrm{kg} /$ day) and low-dose antiplatelet aspirin $(5 \mathrm{mg} / \mathrm{kg} /$ day $)$

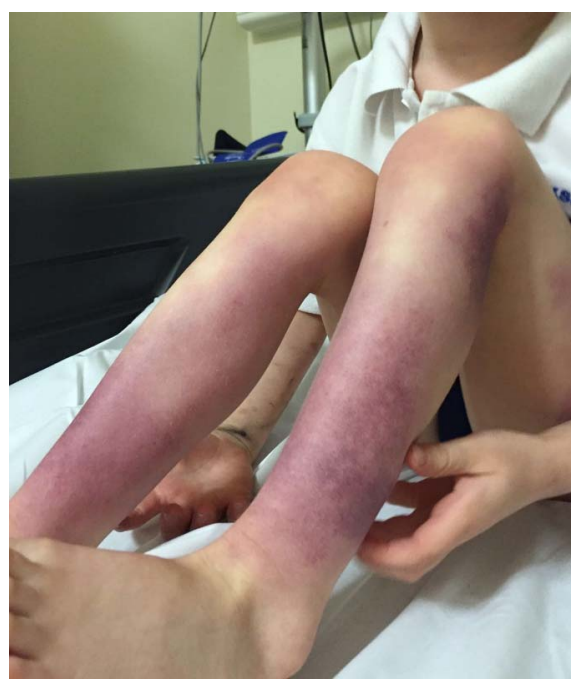

Figure 1 Initial presentation of the purpuric Henoch Schonlein purpura rash.

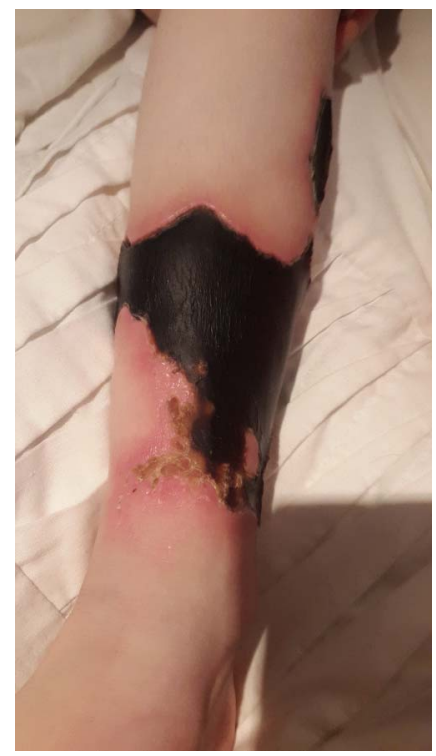

Figure 2 Progression of the lesions to full thickness necrosis.

with significant improvement in skin appearances and no further systemic involvement. The contribution of factor $\mathrm{V}$ Leiden mutation to the extensive necrotic skin manifestation of HSP remains unclear.

\section{Learning points}

- The differential diagnosis of necrotic cutaneous lesions in children includes local or systemic infection, thromboembolic disease, Henoch-Schönlein purpura (HSP), polyarteritis nodosa, antineutrophil cytoplasmic antibodiesassociated vasculitis and purpura fulminans. ${ }^{1}$

- Cutaneous manifestations of HSP are typically benign and self-limiting, although they can be associated with significant morbidity in severe cases. This is particularly true for rarer skin complications such as haemorrhagic, bullous, ulcerated or necrotic lesions. Introduction of immunosuppression may be necessary to control the inflammation and limit the extent of skin necrosis. ${ }^{2}$

- The factors contributing to necrotic complications of HSP in individual patients remain unclear. Inherited thrombophilia tendencies should be considered and explored further in these cases. ${ }^{3}$ 
Contributors Data collection and analysis was performed by SD and AS. The manuscript was written by SD and AS (joint first authorship). DE and SL clinically managed the case and critically revised the manuscript.

Competing interests None declared.

Patient consent Obtained.

Provenance and peer review Not commissioned; externally peer reviewed.

\section{REFERENCES}

1 Weiss P. Pediatric Vasculitis. Pediatr Clin North Am 2012;59:407-23.

2 den Boer S, Pasmans S, Wulffraat N, et al. Bullous lesions in Henoch Schönlein Purpura as indication to start systemic prednisone. Acta Paediatr 2010:99:781-3.

3 Gerke P, Kruger S, Steinhoff J. Henoch-Schonlein purpura, cryofibrinogenaemia, and peripheral gangrene. Nephrol Dial Transplant 1999;14:1746-9.

Copyright 2017 BMJ Publishing Group. All rights reserved. For permission to reuse any of this content visit http://group.bmj.com/group/rights-licensing/permissions.

BMJ Case Report Fellows may re-use this article for personal use and teaching without any further permission.

Become a Fellow of BMJ Case Reports today and you can:

- Submit as many cases as you like

- Enjoy fast sympathetic peer review and rapid publication of accepted articles

- Access all the published articles

- Re-use any of the published material for personal use and teaching without further permission

For information on Institutional Fellowships contact consortiasales@bmjgroup.com

Visit casereports.bmj.com for more articles like this and to become a Fellow 